\title{
Patients with metastatic renal cell carcinoma treated with cabozantinib in the Czech Republic: analysis of four cancer centers
}

\author{
Igor Richtera,b,c, Alexandr Poprach ${ }^{\mathrm{de},}$, Anezka Zemankova ${ }^{f}$, Tomas Buchler $^{\mathrm{b}}$, Jiri Bartos ${ }^{\mathrm{a}}$, Vladimir Samal ${ }^{\mathrm{g}}$, Hana Studentova ${ }^{\mathrm{f}}$, \\ Aneta Rozsypalovab , Josef Dvorak ${ }^{b}$, Ondrej Brom ${ }^{\mathrm{h}}$, Bohuslav Melichar ${ }^{\mathrm{f}}$
}

Aim. The aim of this study was to retrospectively analyze treatment outcomes and tolerance in patients in whom cabozantinib was used after previous targeted therapy.

Patients and Methods. Cabozantinib was administered in dose $60 \mathrm{mg} /$ day, a subset of patients received initial dose of $40 \mathrm{mg} /$ day. The treatment was administered until to progression or unacceptable toxicity. CT scans were assessed according to the RECIST 1.1 and toxicity of treatment was assessed based on the CTCAE (version 4). Kaplan-Meier analysis was used to calculate progression free survival (PFS) and overall survival (OS). We performed a multivariate analysis of risk factors for treatment outcomes (PFS, OS) by Cox regression analysis. All statistics were evaluated at the significance level alpha $=0.05$.

Results. 54 patients with metastatic renal cell carcinoma (mRCC) were evaluated. Median PFS in all patients treated with cabozantinib was 9.3 months $(95 \% \mathrm{Cl} 5.3$ - 13.3). One-year survival was $85.2 \%(95 \% \mathrm{Cl} 72.9$ - $93.4 \%)$. Treatment response was observed in $45.9 \%$ of cases, including one complete remission. Cox regression analysis demonstrated that presence of subsequent treatment was the only factor with a significant effect on OS $(P=0.008)$. Adverse events occurred in $88.9 \%$ of patients, grade $3-4$ in $46.3 \%$.

Conclusion. The analysis of our cohort of patients treated with cabozantinib in the second or higher lines of treatment showed that cabozantinib represents an effective and safe therapy and contributes to longer survival of our mRCC patients

Key words: cabozantinib, metastases, renal cell carcinoma, toxicity

Received: July 29, 2020; Revised: November 12, 2020; Accepted: November 18, 2020; Available online: November, 26, 2020 https://doi.org/10.5507/bp.2020.055

(c) 2022 The Authors; https://creativecommons.org/licenses/by/4.0/

${ }^{a}$ Department of Oncology, Regional Hospital Liberec, Czech Republic

${ }^{b}$ Department of Oncology, First Faculty of Medicine, Charles University and Thomayer Hospital, Prague, Czech Republic

'Technical University of Liberec, Czech Republic

${ }^{d}$ Department of Comprehensive Cancer Care, Masaryk Memorial Cancer Institute, Brno, Czech Republic

${ }^{e}$ Department of Comprehensive Cancer Care, Faculty of Medicine, Masaryk University, Brno, Czech Republic

${ }^{f}$ Department of Oncology, Faculty of Medicine and Dentistry, Palacky University Olomouc and University Hospital Olomouc, Czech Republic ${ }^{9}$ Department of Urology, Regional Hospital Liberec, Czech Republic

${ }^{h}$ ACREA, Czech Republic

Corresponding author: Igor Richter, e-mail: igor.richter@seznam.cz

\section{INTRODUCTION}

The incidence of renal cell carcinoma (RCC) in the Czech Republic is among the highest in the world ${ }^{1}$. Recently, a wide array of new options in systemic treatment of metastatic RCC (mRCC) has become available $^{2}$. Targeted therapy aiming at inhibition of vascular endothelial growth factor receptors (rVEGF) has gained particular importance including tyrosine-kinase inhibitors (TKI) sunitinib, pazopanib, axitinib and sorafenib or anti-VEGF monoclonal antibody bevacizumab ${ }^{3-9}$. In the Czech Republic, pazopanib and sunitinib are most frequently used in the first-line treatment of mRCC patients ${ }^{10,11}$. However, an overwhelming majority of patients gradually develop resistance to their targeted therapy ${ }^{12}$. PD1/PD-L1 interaction inhibiting immunotherapy had been shown in recent studies to prolong long-term survival and is now also available as a treatment option ${ }^{13}$. Other options, such as combined immunotherapy (nivolumab + ipilimumab), or a combination of immunotherapy with a TKI (pembrolizumab + axitinib, avelumab + axitinib) also showed significant efficacy even in mRCC treatmentnaïve patients ${ }^{14-16}$.

Cabozantinib represents another innovative approach to mRCC treatment. This is an orally administered TKI that, in addition to rVEGF, also inhibits other kinases, such as MET, AXL, RET, KIT and FLT3 (ref. ${ }^{17,18}$ ). Preclinical studies have shown that the resistance to rVEGF inhibitors is associated with increased MET and AXL gene expression. Upregulated expression of MET and AXL is then associated with a more aggressive course of the disease and worsened prognosis ${ }^{19}$. Blocking the 
MET and AXL pathways may, therefore, overcome this resistance. METEOR was a pivotal prospective phase III clinical trial that compared cabozantinib to everolimus in patients previously treated with an rVEGF TKI. Cabozantinib was shown to increase progression-free survival, overall survival and response rate compared to everolimus $^{20}$. In the Czech Republic cabozantinib has been in clinical use since 2018 .

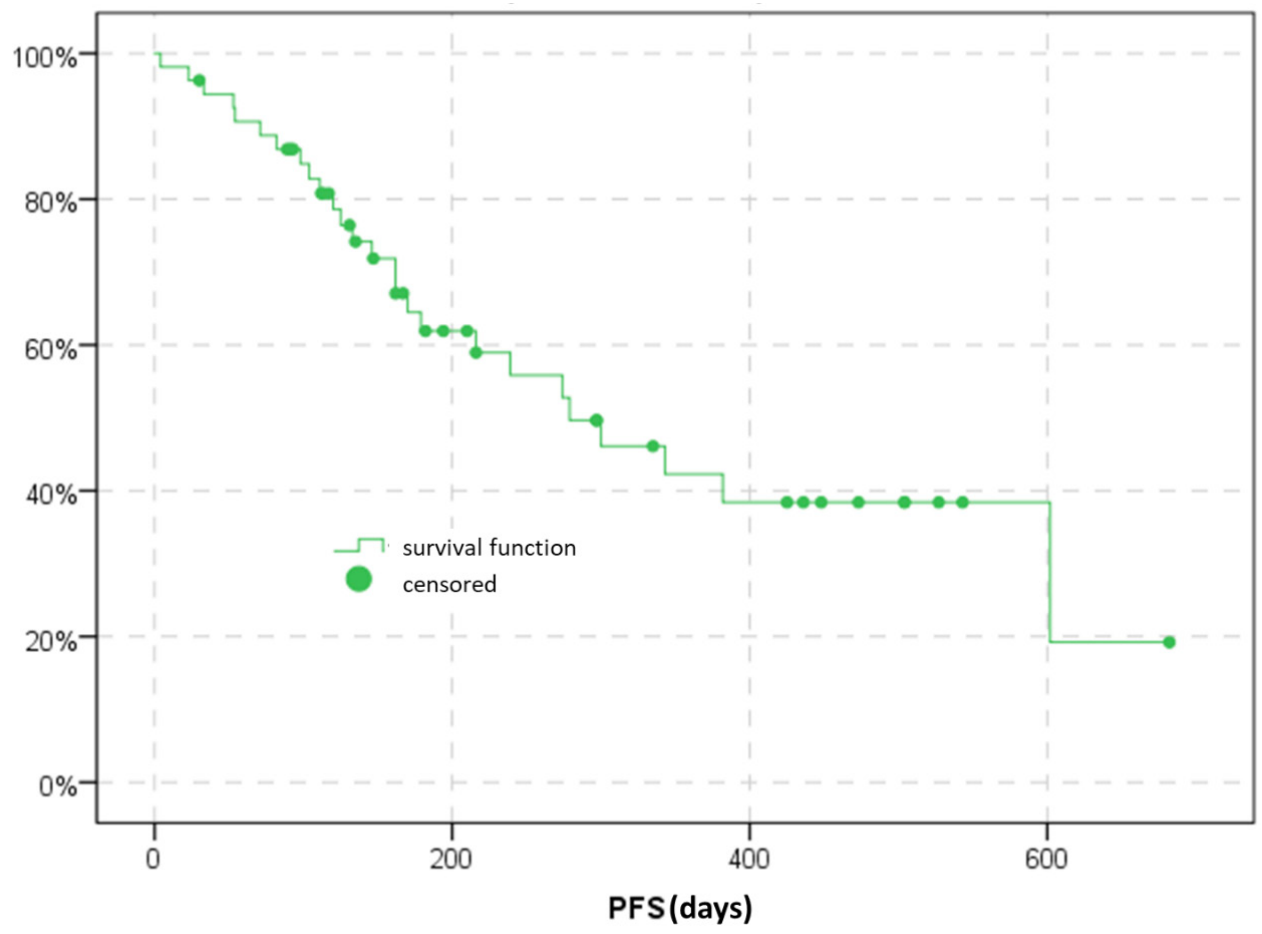

Fig. 1. Progression-free survival - all patients treated with cabozantinib.

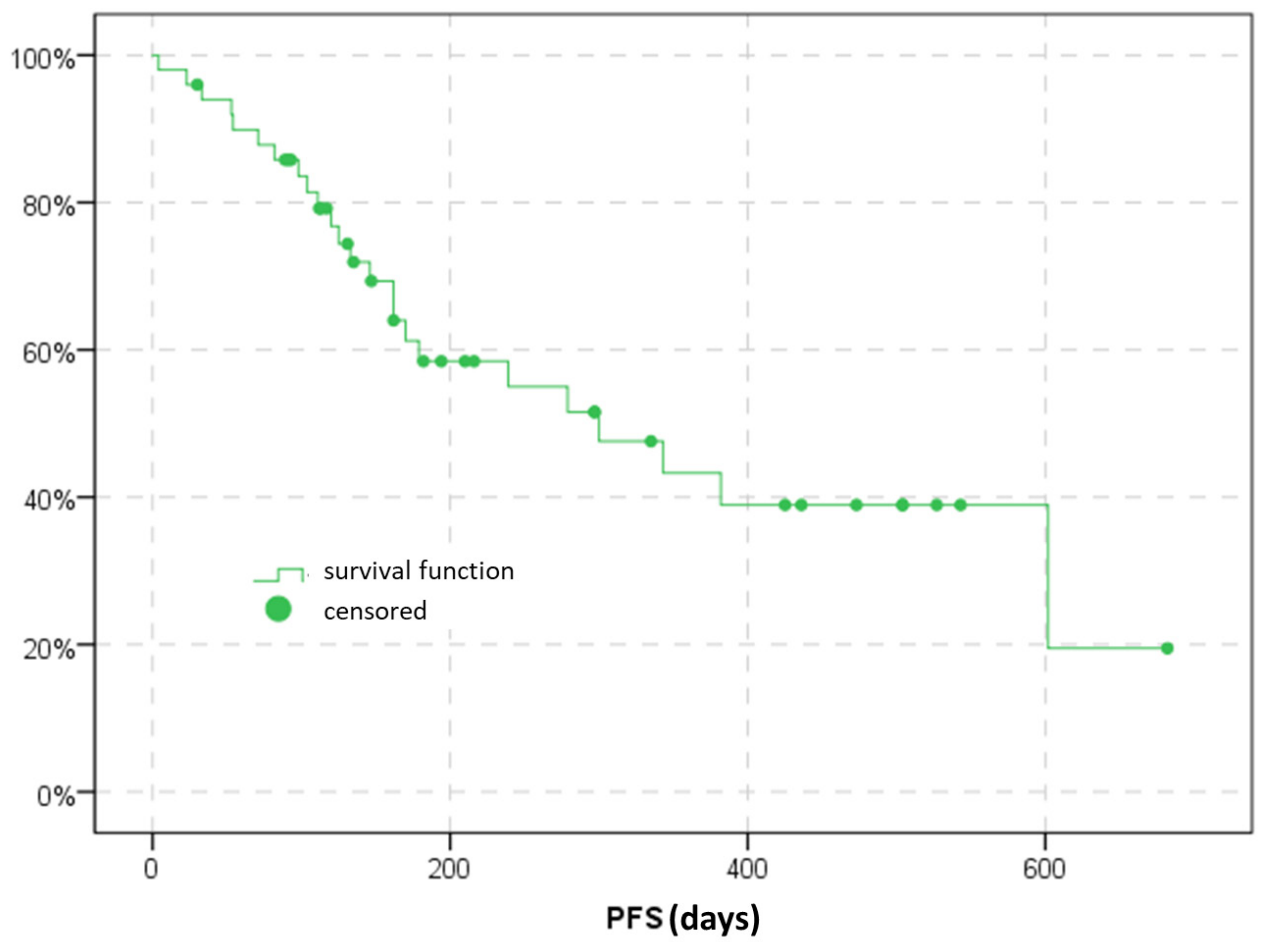

Fig. 2. Progression-free survival - second line only. 


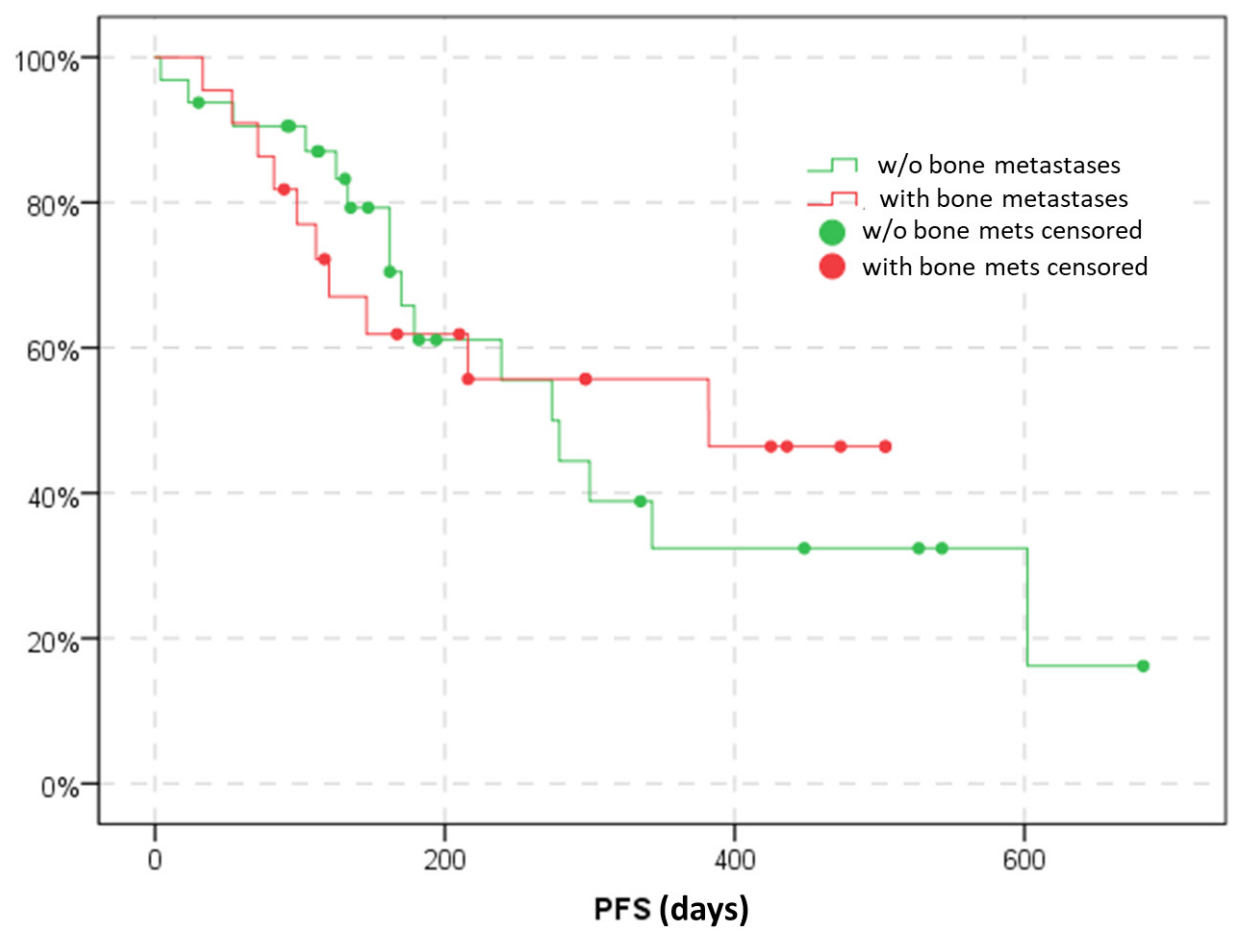

Fig. 3. Progression-free survival of patients with and without (w/o) bone metastases.

\section{PATIENTS AND METHODS}

The study included all patients who began their treatment with cabozantinib between May 2018 and December 2019. Data cut off was $31^{\text {st }}$ March 2020. The patients were taking cabozantinib orally once daily. Initial dose of cabozantinib was $60 \mathrm{mg} /$ day, a subset of patients received initial dose of $40 \mathrm{mg} /$ day. The treatment continued until progression of the disease or signs of unacceptable toxicity. Progression was defined as treatment discontinuation due to disease progression or due to death from any cause. Following withdrawal of cabozantinib treatment, some patients continued on subsequent treatment, as defined by the treating physician.

To evaluate treatment efficacy, CT scans were assessed according to the RECIST 1.1 (Response Evaluation Criteria in Solid Tumors, version 1.1). Toxicity of treatment was assessed based on the CTCAE (Common Terminology Criteria for Adverse Events), version 4.

For statistical purposes, we defined progression-free survival (PFS) as the time interval between the initiation of therapy with cabozantinib and the date disease progression was identified, or the date of the last follow-up visit in patients without progression (censored data). Overall survival (OS) was defined as the time interval between the initiation of cabozantinib therapy and the date of death by any cause or the date of the last follow-up visit in living patients (censored data). Kaplan-Meier analysis was used to calculate PFS and OS. Log-rank test was used to evaluate the difference between groups of patients with metastatic process. We performed a multivariate analysis of risk factors for treatment outcomes (PFS, OS), using the Cox regression analysis. Hazard ratio (HR) was cal- culated with $95 \%$ confidence interval (CI). Values of HR smaller than 1 represent a reduction of risk (favorable prognostic factor), whereas values greater than 1 represent an unfavorable prognostic factor. All statistics were evaluated at the significance level alpha $=0.05$.

\section{RESULTS}

\section{Patient characteristics}

We evaluated 54 patients, 44 (81.5\%) were men. Median age was 65.5 years. Nephrectomy was performed in $41(75.9 \%)$. Metastases were most commonly located in the lungs $(81.5 \%)$. Bone metastatic process was identified in 22 patients $(40.7 \%)$. The majority of patients $(77.8 \%)$ had two or more systems affected with metastases. Cabozantinib was most frequently indicated for second line treatment $(92.6 \%)$. Patients were mostly pre-treated with sunitinib $(50 \%)$ or pazopanib $(43 \%)$. The treatment was initiated with $60 \mathrm{mg} /$ day in 47 patients and $40 \mathrm{mg} /$ day in 7 patients. Table 1 summarizes patients characteristics.

\section{Results}

Median follow-up was 10.6 months. A total of 25 patients discontinued cabozantinib due to disease progression; therapy was discontinued due to adverse events in two cases. At the time of analysis, 27 patients continued their treatment with cabozantinib. Median PFS in all patients treated with cabozantinib was 9.3 months $(95 \%$ CI 5.3 - 13.3) (Fig. 1). Median PFS in patients treated with second line cabozantinib only (excluding higher lines; 50 patients) was 10.0 months (95\% CI 5.1-14.9) (Fig. 2). Median PFS was 12.7 (95\% CI 8.0 - 14.5) months 
in patients with bone metastases, and it was 9.1 (95\% CI 6.6 - 11.7) months in patients without bone metastases. We applied the log-rank test and found no significant difference in PFS between the groups $(P=0.824)$ (Fig. 3$)$. Following discontinuation of cabozantinib, 14 patients were further treated, 13 with nivolumab.

At the time of data analysis, 13 patients had died (24.1\%) and 41 patients were alive. One-year survival was 85.2\% (95\% CI 72.9 - 93.4\%). Treatment response was assessed in 48 patients. Six patients were excluded from the analysis due to short cabozantinib treatment duration. Treatment response was observed in 22 patients $(45.9 \%)$, including one case of complete remission. Clinical benefit was found in $79.2 \%$ of patients. Cox regression analysis did not identify any factors with significant effect on PFS (Table 2). The presence of subsequent treatment was the only factor with a significant effect on OS $(P=0.008)$. A trend towards significance was also observed in patients with better ECOG performance status $(P=0.101)$ and with the first line treatment duration of $\geq 6$ months $(P=0.095)$ (Table 3).

\section{Tolerance}

Adverse events occurred in 48 patients (88.9\%). Grade 3 or 4 toxicity was observed in 25 patients $(46.3 \%)$. The most common adverse events were diarrhea, weight loss, fatigue, loss of appetite, nausea and hand-foot syndrome. The treatment was discontinued due to toxicity in two patients. The dose of cabozantinib was reduced to $40 \mathrm{mg}$ in 24 patients $(44.4 \%)$. Further reduction to $20 \mathrm{mg}$ was reported in 7 patients. The median time to the dose reduction was 68 days. No death related to adverse events of cabozantinib was reported. Adverse events are summarized in Table 4.

\section{DISCUSSION}

Results of randomized clinical studies often cannot be extrapolated to treatment outcomes in routine clinical practice. This may also be because we indicate treatments for a more diverse range of patients, often with additional comorbidities or other factors that would not satisfy the strict eligibility criteria of randomized studies. For example, $69 \%$ of the METEOR study patients had the ECOG performance status of 0 , while this was $45 \%$ in our cohort $^{20}$. In the Czech Republic, treatment with cabozantinib is a newer therapeutic approach as it has only been available since 2018. Therefore, evaluation of treatment outcomes and tolerance in an initial group of treated patients provides an important evidence that might inform future treatment decisions. The present data analysis is the first cabozantinib-treated patient analysis in the Czech Republic. The median PFS in our cohort was 9.3 months. This is a longer median PFS than that reported in the METEOR study (7.4 months) (ref. ${ }^{20}$ ). The longer median PFS in our cohort may be due to a longer duration of time between follow-ups (median 16 weeks in our cohort) and/ or more individualized dosing adjustments to manage adverse events. Furthermore, the response rate was twofold
Table 1. Patients characteristics.

\begin{tabular}{lc}
\hline Patient characteristic & $\mathrm{n}(\%)$ \\
\hline Age & \\
median (years) & 65.5 \\
range (years) & $41-79$ \\
Gender & \\
male & $44(81.5)$ \\
female & $10(18.5)$ \\
Nephrectomy & $41(75.9)$ \\
Primarili metastatic disease & $21(38.9)$ \\
Metastases location & \\
lungs & $44(81.5)$ \\
lymphatic nodes & $34(63)$ \\
bones & $22(40.7)$ \\
liver & $7(13)$ \\
other location & $23(43)$ \\
& \\
Number of metastatic locations & \\
1 & $12(22.2)$ \\
2 & $16(29.6)$ \\
3 & $19(35.2)$ \\
4 and more & $7(13)$ \\
Overall performance status by ECOG & \\
0 & $24(44.4)$ \\
1 & $30(55.6)$ \\
Cabozantinib - line of treatment & \\
2 & $23(3.7)$ \\
3 & \\
Previous targeted treatment & \\
sunitinib & \\
pazopanib & \\
other & \\
& \\
& \\
&
\end{tabular}

higher in our cohort compared to the METEOR study (46 vs. $17 \%$ ). In the METEOR study, grade 3-4 adverse events were observed in $68 \%$ of patients and it was $46 \%$ in our cohort. Similarly, smaller proportion of patients in our cohort had their cabozantinib dose reduced ( 44 vs. $60 \%$ ) and fewer patients had their therapy discontinued due to adverse events ( 4 vs. 9\%). This may also be due to a stricter adverse event recording and reporting rules in prospective randomized studies compared to retrospective data analyses. Several retrospective studies assessing treatment with cabozantinib in second or higher lines have been published. An analysis from four centers in Poland evaluated a total of 115 patients, half of whom had bone metastases. Median PFS was 12.5 months (95\% CI 9.2 - 14.2). Treatment response was observed in $19 \%$ of patients, $56 \%$ patients achieved stable disease. The most common grade 3 or 4 adverse events were fatigue (23\%), hand-foot syndrome (12\%) and diarrhea (10\%). Only 4\% of patients discontinued their treatment due to toxicity ${ }^{21}$. A retrospective analysis published by Italian authors presented data from a set of 94 patients from 24 centers. The authors described treatment response in $36 \%$ of patients and 
Table 2. Factor impact on progression-free survival.

\begin{tabular}{lcc}
\hline Factor & HR $(95 \% \mathrm{CI})$ & $P$ \\
\hline Age $(<65$ vs $\geq 65$ year) & $0.810(0.356-1.841)$ & 0.616 \\
Gender (female vs. male) & $0.435(0.128-1.470)$ & 0.181 \\
Nephrectomy (yes vs. no) & $0.905(0.338-2.421)$ & 0.842 \\
Primary localized disease (yes vs. no) & $0.715(0.323-1.582)$ & 0.408 \\
Lung metastases (yes vs. no) & $1.186(0.406-3.466)$ & 0.755 \\
Metastases in LN (yes vs. no) & $0.810(0.363-1.809)$ & 0.608 \\
Bone metastases (yes vs. no) & $0.913(0.409-2.038)$ & 0.824 \\
Prior TKI (pazopanib vs. sunitinib) & $1.089(0.461-2.572)$ & 0.846 \\
PS (0 vs. 1) & $0.828(0.373-1.842)$ & 0.645 \\
First line duration ( $\geq 12$ vs. < 12 months) & $0.532(0.203-1.393)$ & 0.199 \\
First line duration ( $\geq 6$ vs. <6 months) & $0.564(0.234-1.356)$ & 0.200 \\
Grade 3-4 toxicity (yes vs. no) & $0.862(0.392-1.895)$ & 0.711 \\
\hline
\end{tabular}

Table 3. Factor impact on overall survival.

\begin{tabular}{llc}
\hline Factor & HR $(95 \%$ CI $)$ & $P$ \\
\hline Age (<65 vs $\geq 65$ year) & $0.952(0.309-2.923)$ & 0.933 \\
Gender (female vs. male) & $0.289(0.037-2.237)$ & 0.235 \\
Nephrectomy (yes vs. no) & $0.892(0.243-3.269)$ & 0.863 \\
Primary localized disease (yes vs. no) & $0.487(0.163-1.450)$ & 0.196 \\
Lung metastases (yes vs. no) & $0.773(0.166-3.607)$ & 0.743 \\
Metastases in LN (yes vs. no) & $0.598(0.199-1.799)$ & 0.360 \\
Bone metastases (yes vs. no) & $1.905(0.579-6.269)$ & 0.289 \\
Prior TKI (pazopanib vs. sunitinib) & $0.732(0.205-2.609)$ & 0.631 \\
PS (0 vs. 1) & $0.277(0.059-1.258)$ & 0.101 \\
First line duration ( $\geq 12$ vs. $<12$ months) & $0.298(0.062-1.429)$ & 0.130 \\
First line duration ( $\geq 6$ vs. <6 months) & $0.336(0.093-1.210)$ & 0.095 \\
Grade 3-4 toxicity (yes vs. no) & $0.544(0.171-1.732)$ & 0.303 \\
Subsequent treatment (yes vs. no) & $0.110(0.021-0.561)$ & 0.008 \\
\hline
\end{tabular}

Table 4. Summary of adverse events.

\begin{tabular}{lcc}
\hline Adverse event & $\begin{array}{c}\text { Total } \\
\mathrm{n}(\%)\end{array}$ & $\begin{array}{c}\text { Grade } 3-4 \\
\mathrm{n}(\%)\end{array}$ \\
\hline Diarrhea & $27(50.0)$ & $15(27.8)$ \\
Loss of weight & $20(37.0)$ & $3(5.6)$ \\
Fatigue & $19(35.2)$ & $3(5.6)$ \\
Hand-foot syndrome & $15(27.8)$ & $2(3.7)$ \\
Nausea & $12(22.2)$ & $3(5.6)$ \\
Loss of appetite & $9(16.7)$ & $3(5.6)$ \\
Stomatitis & $8(14.8)$ & $1(1.9)$ \\
Arterial hypertension & $6(11.1)$ & $1(1.9)$ \\
ALT/AST elevation & $6(11.1)$ & $1(1.9)$ \\
Anemia & $4(7.4)$ & $1(1.9)$ \\
Pyrosis & $4(7.4)$ & $1(1.9)$ \\
Hypothyroidism & $3(5.6)$ & 0 \\
Acneiform exanthema & $3(5.6)$ & 0 \\
Leukopenia & $3(5.6)$ & 0 \\
Thrombocytopenia & $2(3.7)$ & $1(1.9)$ \\
Hypokalemia & $2(3.7)$ & $1(1.9)$ \\
Pulmonary embolism & $1(1.9)$ & $1(1.9)$ \\
Stroke & $1(1.9)$ & $1(1.9)$ \\
\hline
\end{tabular}


stable disease in $34 \%$ of patients. Median PFS was 8.0 months, i.e. shorter than in our cohort. This may be because nearly one third of patients had lower performance status and started their treatment on a reduced dose. In addition, only $29 \%$ of patients received cabozantinib as the second line of their treatment, up to $52 \%$ were treated in fourth or higher lines. The cause of the difference in median PFS may by the bias in patient selection. Grade 3-4 adverse events were described in $36 \%$ of patients ${ }^{22}$. Both above mentioned studies, together with results of our observations, confirm acceptable tolerance of treatment. This may also be because treatment with cabozantinib is indicated by clinicians, who are familiar with adverse effects normally associated with TKIs and with their management. In the Czech Republic, rVEGF TKIs have been used in clinical practice for more than 10 years. The majority of adverse effects observed with TKIs are predictable and patients can be educated on what adverse effects they might experience and how to respond. Benefits of cabozantinib in patients with bone metastases associated with poor prognosis in $\mathrm{mRCC}$ are frequently discussed $^{23,24}$. Preclinical studies on prostate cancer cells demonstrated that cabozantinib affects bone remodeling, with biphasic impact on osteoblasts and inhibition of osteoclasts $^{25}$. The METEOR study has shown a more pronounced effect of cabozantinib in patients with bone metastases compared to everolimus. Median PFS was significantly longer ( 7.4 vs. 2.7 months; HR 0.33, 95\% CI $0.21-0.51$ ), as was median OS (20.1 vs. 12.1 months; HR $0.54,95 \%$ CI $0.34-0.84)$. Response rate was $17 \%$ in patients treated with cabozantinib and $0 \%$ in patients on everolimus. Patients with bone metastases represented $23 \%$ of all patients treated with cabozantinib ${ }^{26}$. In our cohort, $40.7 \%$ of patients had bone metastases and this is, once again, because cabozantinib is being considered as the treatment of choice in patients who failed on the first line of treatment and have bone metastases. Similarly, half of the patients evaluated in a study by Polish authors had bone metastases ${ }^{21}$. In our cohort, we observed longer median PFS in patients with bone metastatic processes compared to patients without bone injury by 3.6 months, although this result was not statistically significant $(P=0.824)$. On the other hand the response rate was higher in patients without bone metastases compared with patients with bone metastases (53.3 vs. $38.3 \%$ ) in our cohort. The phase II CABOSUN study provided further evidence of the less favorable prognostic outcome in patients with bone metastases. The study evaluated targeted treatment-naïve mRCC patients with intermediate and poor prognosis. The study showed longer PFS on cabozantinib compared to sunitinib ${ }^{27,28}$. A subgroup analysis showed that treatment with cabozantinib provided greater benefit in patients with bone metastases than in patients without them in terms of median PFS (5.5 versus 3.3 months; HR 0.51, 95\% CI 0.16 - 0.63) $\left(\right.$ ref. $\left.^{29}\right)$. We also used the Cox analysis to evaluate the effect of other factors on treatment results. We did not identify any factor that significantly affected PFS. OS was significantly impacted by whether or not a subsequent line of treatment was used. Nivolumab was the most frequently used subsequent treatment in our cohort ( $93 \%$ of cases, $P=0.008$ ). A trend towards positive effect on OS was observed in patients with better performance status $(P=0.101)$. Previous therapy (sunitinib or pazopanib) did not have any significant effect on the efficacy of cabozantinib. This finding is in line with the conclusions of the METEOR study $^{30}$. Similarly, treatment duration did not have any significant impact on cabozantinib efficacy, even though a trend was observed towards longer OS in patients treated $\geq 6$ months $(P=0.095)$. When deciding about the second line treatment after TKI therapy in clinical practice, we most frequently consider cabozantinib and nivolumab since, similarly to cabozantinib, nivolumab showed improvement of overall survival and higher treatment response in comparison to everolimus ${ }^{13}$. However, nivolumab did not significantly prolong median PFS. Direct comparison of cabozantinib and nivolumab treatment efficacy is not available. Indirect statistical comparison did not confirm any significant difference between cabozantinib and nivolumab in terms of OS, while cabozantinib significantly prolonged PFS (HR 0.58, 95\% CI 0.34 - 0.98) $\left(\right.$ ref. $\left.^{31}\right)$. The significant impact of nivolumab on OS but not PFS is associated with the specifics of how immunotherapy exerts its effect. Cabozantinib has fast onset of therapeutic response with a median of 1.9 months ${ }^{6}$. Therefore, in summary, we consider cabozantinib in patients rapidly progressing on a previous TKI in order to achieve fast treatment response, in case of bone metastases and in patients who tolerated their previous TKI treatment well. However, no clear predictive factors for cabozantinib treatment have been identified so far. The number of treatment options, particularly in the first line of mRCC treatment, is continuously growing and, in specific groups of patients, we might be deciding between combined immunotherapy with nivolumab and ipilimumab, monotherapy with cabozantinib, or a combination of pembrolizumab with axitinib or avelumab with axitinib $^{14-16,27}$. The results of the CheckMate-9ER study assessing first line mRCC treatment with a combination of nivolumab and cabozantinib are also to be soon published. Despite these advanced treatment options, we will still have $\mathrm{mRCC}$ patients treated with first line TKIs (sunitinib, pazopanib) in whom, upon progression, second line treatment with cabozantinib might be an appropriate treatment option. Further prognostic and predictive factors are also being sought in RCC. Similar to other types of cancer, we have already conducted an analysis of primary cilia in RCC patients ${ }^{32,33}$. Overall survival according to the frequency of primary cilia was significantly shorter in patients with higher frequency than in patients with lower frequency. Median OS was also significantly shorter in patients with higher CD8+ TIL and higher $(>25 \%)$ PD $1+$ expression than in patients with lower $(<25 \%)$ expression. The study provides the first data on the potential association and combined prognostic significance of frequency of primary cilia, PD1+ cells and CD8+ TIL in patients with clear cell renal cancer. 


\section{CONCLUSION}

The analysis of our cohort of patients treated with cabozantinib in the second or higher lines of treatment showed that cabozantinib is an effective and safe therapy and contributes to longer survival of our mRCC patients.

Author contributions: IR: manuscript writing, literature search, data collection, data interpretation; AP: data collection; AZ: data collection; TB: data collection; JB: data interpretation; VS: data collection; HS: data collection; AR: data collection; JD: data interpretation; OB: statistical analysis; BM: data analysis, data interpretation.

Conflict of interest statement: The authors state that there are no conflict of interest regarding the publication of this article.

\section{REFERENCES}

1. Dušek L, Mužík Jan, Kubásek M, Koptíková J, Žaloudík J, Vyzula R. Epidemiologie zhoubných nádorů v České republice [online]. Masarykova univerzita, [2005], [cit. 2020-10-16]. Available from www: http://www.svod.cz. Verze 7.0 [2007], ISSN 1802-8861. (In Czech)

2. Richter I, Dvořák J. Treatment of metastatic renal cell carcinoma. Klin Onkol Spring 2018; 31:10-116.

3. Motzer RJ, Hutson TE, Tomczak P, Michaelson MP, Bukowski RM, Rixe O, Oudard S, Negrier S, Szczylik C, Kim ST, Chen I, Bycott PW, Baum CM, Figlin RA. Sunitinib versus interferon alfa in metastatic renal-cell carcinoma. N Eng J Med 2007; 356:115-24.

4. Motzer RJ, Hutson TE, Tomczak P, Michaelson MD, Bukowski RM, Oudard S, Negrier S, Szczylik C, Pili R, Bjarnason GA, Garcia-del-Muro X, Sosman JA, Solska E, Wilding G, Thompson JA, Kim ST, Chen I, Huang $X$, Figlin RA. Overall survival and updated results for sunitinib compared with interferon alfa in patients with metastatic renal cell carcinoma. J Clin Oncol 2009;27:3584-90.

5. Sternberg CN, Davis ID, Mardiak J, Szczylik C, Lee E, Wagstaff J, Barrios CH, Salman P, Gladkov OA, Kavina A, Zarbá JJ, Chen M, McCann L, Pandite LN, Roychowdhury DF, Hawkins RE. Pazopanib in locally advanced or metstatic renal cell carcinoma: results of a randomized phase III trial. J Clin Oncol 2010; 28:1061-68.

6. Motzer RJ, Hutson TE, Cella D, Reeves J, Hawkins R, Guo J, Nathan P, Staehler M, De Souza P, Merchan JR, Boleti E, Fife K, Jin J, Jones R, Uemura H, De Giorgi U, Harmenberg U, Wang J, Sternberg CN, Deen K, McCann L, Hackshaw MD, Crescenzo R, Pandite LN, Choueiri TK. Pazopanib versus sunitinib in metastatic renal-cell carcinoma. N Engl J Med 2013;369:722-31.

7. Escudier B, Eisen T, Stadler WM, Szczylik C, Oudard S, Staehler M, Negrier S, Chevreau C, Desai AA, Rolland F, Demkow T, Hutson TE, Gore M, Anderson S, Hofilena G, Shan M, Pena C, Lathia C, Bukowski RM. Sorafenib for treatment of renal cell carcinoma: Final efficacy and safety results of the phase III treatment approaches in renal cancer global evaluation trial. J Clin Oncol 2009;27:3312-18.

8. Motzer RJ, Escudier B, Tomczak P, Hutson TE, Michaelson MD, Negrier S, Oudard S, Gore ME, Tarazi J, Hariharan S, Chen C, osbrook B, Kim $\mathrm{S}$, Rini BI. Axitinib versus sorafenib as second-line treatment for advanced renal cell carcinoma: overall survival analysis and updated results from a randomised phase 3 trial. Lancet Oncol 2013;14:55262.

9. Escudier B, Bellmunt J, Négrier S, Bajetta E, Melichar B, Bracarda S, Ravaud A, Golding S, Jethwa S, Sneller V. Phase III trial of bevacizumab plus interferon alfa-2a in patients with metastatic renal cell carcinoma (AVOREN): final analysis of overal survival. J Clin Oncol 2010;28:2144-50.

10. Poprach A, Fiala O, Chloupkova R, Melichar B, Lakomy R, Petrakova K, Zemanova M, Kopeckova K, Slaby O, Studentova H, Kopecký J, Kiss I, Finek J, Dusek L, Buchler T. Pazopanib for Metastatic Renal Cell
Carcinoma: A Registry-based Analysis of 426 Patients. Anticancer Res 2018;38:449-56.

11. Poprach A, Bortlíček Z, Büchler T, Melichar B, Lakomý R, Vyzula R, Brabec P, Svoboda M, Dušek L, Gregor J. Patients with advanced and metastatic renal cell carcinoma treated with targeted therapy in the Czech Republic: Twenty cancer centres, six agents, one database. Med Oncol 2012;29:3314-20.

12. Duran I, Lambea J, Maroto P, González-Larriba JL, Flores L, GranadosPrincipal S, Graupera M, Sáez B, Vivancos A, Casanovas O. Resistance to Targeted Therapies in Renal Cancer: The Importance of Changing the Mechanism of Action. Target Oncol 2017;12:19-35.

13. Motzer RJ, Escudier B, McDermott DF, George S, Hammers HJ, Srinivas S, Tykodi SS, Sosman JA, Procopio G, Plimack ER, Castellano D, Choueiri TK. Nivolumab versus everolimus in advanced renal cell carcinoma. N Engl J Med 2015;373:1903-13.

14. Motzer RJ, Tannir NM, McDermott DF, Frontera OA, Melichar B, Choueiri TK, Plimack ER, Barthélémy P, Porta $C$, George $S$, Powles T, Donskov F, Neiman V, Kollmannsberger CK, Salman P, Gurney H, Hawkins R, Ravaud A, Grimm MO, Bracarda S, Barrios CH, Tomita Y, Castellano D, Rini BI, Chen AC, Mekan S, McHenry MB, Wind-Rotolo M, Doan J, Sharma P, Hammers HJ, Escudier B. Nivolumab plus ipilimumab versus sunitinib in advanced renal-cell carcinoma. N Engl J Med 2018;378:1277-99.

15. Motzer RJ, Penkov K, Haanen J, Rini B, Albiges L, Campbell MT, Venugopal B, Kollmannsberger C, Negrier S, Uemura M, Lee JL, Vasiliev A, Miller Jr WH, Gurney H, Schmidinger M, Larkin J, Atkins MB, Bedke J, Alekseev B, Wang J, Mariani M, Robbins PB, Chudnovsky A, Fowst C, Hariharan S, Huang B, Di Pietro A, Choueiri TK. Avelumab plus axitinib versus sunitinib for advanced renal-cell carcinoma. $\mathrm{N}$ Eng J Med 2019;380:1103-15.

16. Rini BI, Plimack ER, Stus V, Gafanov R, Hawkins R, Nosov D, Pouliot F, Alekseev B, Soulières D, Melichar B, Vynnychenko I, Kryzhanivska A. Pembrolizumab plus axitinib versus sunitinib for advanced renal-cell carcinoma. N Eng J Med 2019;380:1116-27.

17. Yakes FM, Chen J, Tan J, Yamaguchi K, Shi Y, Yu P, Qian F, Chu F, Bentzien F, Cancilla B, Orf J, You A, Laird AD, Engst S, Lee L, Lesch J, Chou YC, Joly AH. Cabozantinib (XL184), a novel MET and VEGFR2 inhibitor, simultaneously suppresse metastasis, angiogenesis, and tumor growth. Mol Cancer Ther 2011;10:2298-2308.

18. Tannir NM, Schwab G, Grunwald V. Cabozantinib: an active novel multikinase inhibitor in renal cell carcinoma. Curr Oncol Rep 2017;19:14.

19. Zhou L, Liu XD, Sun $M$, Zhang X, German $P$, Bai S, Ding Z, Tannir N, Wood CG, Matin SF, Karam JA, Tamboli P, Sircar K, Rao P, Rankin EB, Laird DA, Hoang AG, Walker CL, Giaccia AJ, Jonasch E. Targeting MET and AXL overcomes resistence to sunitinib therapy in renal cell carcinoma. Oncogene 2016;35:2687-97.

20. Choueiri TK, Escudier B, Powles T, Mainwaring PN, Rini BI, Donskov F, Hammers H, Hutson TE, Lee JL, Peltola K, Roth BJ, Bjarnason GA. Cabozantinib versus everolimus in advanced renal-cell carcinoma. N Engl J Med 2015;373:1814-23.

21. Bodnar L, Kopczyńska A, Żołnierek J, Wieczorek-Rutkowska M, Chrom P, Tomczak P. Real-world Experience of Cabozantinib as Second or Subsequent Line Treatment in Patients With Metastatic Renal Cell Carcinoma: Data From the Polish Managed Access Program. Clin Genitourine Cancer 2019;17:e556-e564.

22. Procopio G, Prisciandaro M, lacovelli R, Cortesi E, Fornarini G, Facchini G, Cartenì G, Sabbatini R, Del Bene G, Galli L, Caserta C, Multari AG, Bregni M, Massari F, Buti S, De Giorgi U, Zustovich F, Milella M, Calabrò F, Mancini ML, Tortora G, Vernieri C, Santini D, Sorarù M, Ricotta R, Masini C, Tucci M, Fedeli SL, Ortega C, Mecozzi A, Ratta R, Sternberg CN, Verzoni E. Safety and Efficacy of Cabozantinib in Metastatic Renal-Cell Carcinoma: Real-World Data From an Italian Managed Access Program. Clin Genitourinal Cancer 2018;16:e945e951.

23. McKay RR, Kroeger N, Xie W, Lee JL, Knox JJ, Bjarnason GA, MacKenzie MJ, Wood L, Srinivas S, Vaishampayan UN, Rha SY, Pal SK, Donskov F Tantravahi SK, Rini BI, Heng DYC, Choueiri TK. Impact of bone and liver metastases on patients with renal cell carcinoma treated with targeted therapy. Eur Urol 2014;65:577-84.

24. Beuselinck B, Oudard S, Rixe O, Wolter P, Blesius A, Ayllon J, Elaidi R, Schöffski P, Barrascout E, Morel A, Escudier B, Lang H, Zucman-Rossi $J$, Medioni J. Negative impact of bone metastasis on outcome in 
clear3 cell renal cell carcinoma treated with sunitinib. Ann Oncol 2011;22:794-800.

25. Dai J, Zhang H, Karatsinides A, Keller JM, Kozloff KM, Aftab DT, Schimmoller F, Evan Keller ET. Cabozantinib inhibits prostate cancer growth and prevents tumor - induced bone lesions. Clin Cancer Res 2014;20:617-30.

26. Escudier B, Powles T, Motzer RJ, Olencki T, Frontera OA, Oudard S, Rolland F, Tomczak P, Castellano D, Appleman LJ, Drabkin H, Vaena D, Milwee S, Youkstetter J, Lougheed JC, Bracarda S, Choueiri TK. Cabozantinib, a New Standard of Care for Patients With Advanced Renal Cell Carcinoma and Bone Metastases? Subgroup Analysis of the METEOR Trial. J Clin Oncol 2018;36:765-72.

27. Choueiri TK, Halabi S, Sanford BL, Hahn O, Michaelson MD, Walsh MK, Feldman DR, Olencki T, Picus J, Small EJ, Dakhil S, George DJ, Morris MJ. Cabozantinib Versus Sunitinib As Initial Targeted Therapy for Patients With Metastatic Renal Cell Carcinoma of Poor or Intermediate Risk: The Alliance A031203 CABOSUN Trial. J Clin Oncol 2017;35:591-97.

28. Choueiri TK, Hessel C, Halabi S, Sanford B, Michaelson MD, Hahn O, Walsh M, Olencki T, Picus J, Small EJ, Dakhil S, Feldman DR, Mangeshkar M, Scheffold C, George D, Morris MJ. Cabozantinib versus sunitinib as initial therapy for metastatic renal cell carcinoma of intermediate or poor risk (Alliance A031203 CABOSUN randomised trial): Progression-free survival by independent review and overall survival update. Eur J Cancer 2018; 94:115-25.
29. George DJ, Hessel C, Halabi S, Michaelson MD, Hahn O, Walsh M, Picus J, Small EJ, Dakhil S, Feldman DR, Mangeshkar M, Scheffold C, Morris MJ, Choueiri TK. Cabozantinib Versus Sunitinib for Untreated Patients with Advanced Renal Cell Carcinoma of Intermediate or Poor Risk: Subgroup Analysis of the Alliance A031203 CABOSUN trial. Oncologist 2019;24:1497-1501.

30. Powles T, Motzer RJ, Escudier B, Pal S, Kollmannsberger C, Pikiel J, Gurney H, Rha SY, Park SH, Geertsen PF, Gross-Goupil M, Grande E, Suarez C, Markby DW, Arroyo A, Dean M, Choueiri TK, George D. Outcomes based on prior therapy in the phase 3 METEOR trial of cabozantinib versus everolimus in advanced renal cell carcinoma. Br J Cancer 2018;119:663-69.

31. Porta C, Szczylik C, Casciano R, Fu S, Amzal B, Lister J, Karcher H, Meng J, Neumann M, Dinet J. Second-line cabozantinib versus nivolumab in advanced renal cell carcinoma: Systematic review and indirect treatment comparison. Crit Rev Oncol Hematol 2019;139:143-48.

32. Dvorak J, Nikolov DH, Dusek L, Filipova A, Richter I, Buka D, Ryska A, Mokry J, Filip S, Melichar B, Buchler T, Abrahamova J. Association of the combined parameters including the frequency of primary cilia, CD8+ tumor infiltrating lymphocytes and PD-1 expression with the outcome in intestinal cancer. J BUON 2017;22:1477-87.

33. Rozsypalova A, Rosova B, Filipova A, Nikolov DH, Chloupkova R, Richter I, Proks J, Zachoval R, Matej R, Melichar B, Buchler T, Dvorak J. Negative prognostic significance of primary cilia, CD8+ tumor infiltrating lymphocytes and PD1+ cells expression in clear cell renal cancer. J BUON 2019;24:1644-51. 